\title{
CORRECTION
}

\section{Correction to: GAMAH-R: a new mining rock slope classification system}

\author{
Flávio Affonso Ferreira Filho ${ }^{1} \cdot$ Romero César Gomes ${ }^{1} \cdot$ Teófilo Aquino Vieira da Costa $^{2}$
}

Published online: 23 July 2021

(c) Springer-Verlag GmbH Germany, part of Springer Nature 2021

\section{Correction to: Bulletin of Engineering Geology and the \\ Environment (2021) \\ https://doi.org/10.1007/s10064-021-02330-2}

The original article contains an error in author name. "Ferreira" was listed twice during processing.

The original article has been corrected.

The original article can be found online at https://doi.org/10.1007/ s10064-021-02330-2.

Flávio Affonso Ferreira Filho

flavio.affonso@professor.gorceix.org.br

1 Núcleo de Geotecnia, Universidade Federal de Ouro Preto,

Bauxita, Ouro Preto, State of Minas Gerais, 35400-000,

Brazil

2 Vale S. A, Rio de Janeiro, MG, Brazil 